\title{
Plate tectonic setting of the Andean Cordillera
}

\author{
Laboratorio de Tectónica Andina, Universidad de Buenos Aires, Argentina. E-mail: andes@gl.fcen.uba.ar
}

\begin{abstract}
The Andes are a natural laboratory for the study of the interaction between subduction of the oceanic plate and active geological processes. Inter- and intraplate seismicity, volcanic activity, thick- and thin-skinned fold and thrust belts, and foreland basin subsidence, in conjunction with space geodetic observations, contribute to characterize the present plate tectonic setting of discrete segments of the Andes. The inherited geological history, as well as the present tectonic setting, is responsible for the unique geology of the Northern, Central, and Southern Andes. The Northern Andes are the result of Mesozoic and Cenozoic collisions of oceanic terranes, prior to the present Andean-type setting. The Central Andes have a long history of subduction and volcanic arc activity, while the Southern Andes record the closing of a back-arc oceanic basin, and almost no volcanic arc activity. These major geological units have along-strike variations in the subduction geometry that controls the different volcanic zones. The link between trench collision of aseismic ridges and flat-slab segments plays an important role in the conclusion of the volcanic activity. The collision of seismic ridges also produces a volcanic arc gap, but with an unusual suite of near trench magmatism, plateau basalts, and adakites.
\end{abstract}

\section{Introduction}

The western continental margin of South America has a mountain chain along more than $8,000 \mathrm{~km}$, with elevations up to 7,000 $\mathrm{m}$ a.s.1., being the type locality of the Andean orogen. This orogenic type has produced the highest non-collisional mountains in the world. However, when this chain is analyzed in detail it is evident that a great variety of processes has produced its present geology. As most of these processes are still active, the Andean Cordillera has become a natural laboratory for studying the relationships between magmatic rocks and tectonic processes, deformation and the origin of sedimentary basins, transmission of the stress and resulting structures, and rates of present and past deformation, among others. This variety of geological processes has produced distinctive segments along the Andes with diverse characteristics and tectonic settings (Figures 1 and 2).

Several authors have analyzed the Andes and proposed different geological classifications in order to identify discrete segments with somewhat homogeneous geological properties. Among these classifications, the proposal of Gansser (1973) was the first to be based on first order tectonic differences among the major segments of the Andean Cordillera. This author recognized as major geological units the Northern, Central, and Southern Andes (Figure 1). Although different authors agree with this three-fold division (see Auboin et al., 1973; Zeil, 1979; Thorpe, 1984; Mpodozis and Ramos, 1989; Kley et al., 1999), the limits and the facts used to char- acterize the different segments are widely variable. The present overview will focus on the major geological differences among these segments, based on today's plate-tectonic knowledge of this mountain chain.

\section{Major geological provinces}

The Andes north of the Golfo de Guayaquil are unique, as established by Gansser (1973). The Northern Andes record an important accretion of oceanic crust during Jurassic, late Cretaceous, and Paleogene times. As a result, the Western Cordillera of Colombia and Ecuador is mainly constituted of an oceanic basement that during accretion was related to ophiolite obduction, important penetrative deformation and metamorphism, in cases up to blue schist facies. Further north, the emplacement of the Caribbean nappes was related to the collision of an island arc system, the Bonaire block, during Paleogene times (Bosch and Rodríguez, 1992, Kellogg and Bonini, 1982). Subsequent tectonic inversion of normal faults during Neogene times uplifted the Mérida Andes (Colleta et al., 1997) and overimposed strike-slip partitioning to dominate present tectonics (Schubert, 1982).

The Central Andes between the Golfo de Guayaquil $\left(4^{\circ} \mathrm{S}\right)$ and the Golfo de Penas (46 $\left.30^{\prime} \mathrm{S}\right)$ are a typical Andean-type orogen where tectonics was driven by subduction. Within this general region several sectors record a complex tectonic history, punctuated by changes in the Wadati-Benioff geometry and different uplift mechanisms.

The geology north of Arequipa $\left(14^{\circ} \mathrm{S}\right)$, the northern sector of the Central Andes, is the result of extensional tectonics and subduction during early Mesozoic times (Mégard, 1987). Subsequent compression and migration of magmatism, and deformation towards the foreland uplifted the Peruvian Andes, with the development of the present flat-slab subduction in the last 5 My (Sébrier and Soler, 1991).

The central sector of the Central Andes comprises southern Peru, Bolivia, and northern Argentina $\left(14^{\circ}-27^{\circ} \mathrm{S}\right)$. It is characterized by normal subduction and an active volcanic arc. The present uplift of the Altiplano-Puna plateau is thermally induced (Isacks, 1988). Variation in the Wadati-Benioff geometry during Neogene times was responsible for a wider magmatic arc during early Miocene times and therefore higher thermal gradients that favored softening of the lower crust and later important thickening and uplift of the Eastern Cordillera and the Subandean belt during late Miocene times (Allmendinger et al., 1997).

The southern sector of the Central Andes is highly variable. The flat slab segment $\left(27^{\circ}-33^{\circ} 30^{\prime} \mathrm{S}\right)$ with strong active deformation, has a complex High Cordillera, a Precordillera thin-skinned belt and the Sierras Pampeanas. These basement blocks uplifted during shallowing of the flat-slab since the Late Miocene. It records an initial migration of the magmatic arc by crustal erosion (Ramos, 1988), and a rapid migration associated with the shallowing of the subduction with a volcanic front $700 \mathrm{~km}$ from the trench during Quaternary times (Kay et al., 1991). South of the flat-slab segment, the Andes are characterized by the Principal Cordillera and a series of minor uplifts of the San Rafael block (Kozlowski et al., 1993). The main Andean uplift south of $38^{\circ} \mathrm{S}$ is related to late Cretaceous deformation. The present stress partitioning of the Iquiñe-Ofqui fault (Hervé, 1994) produced a decoupling between the forearc and the retroarc 


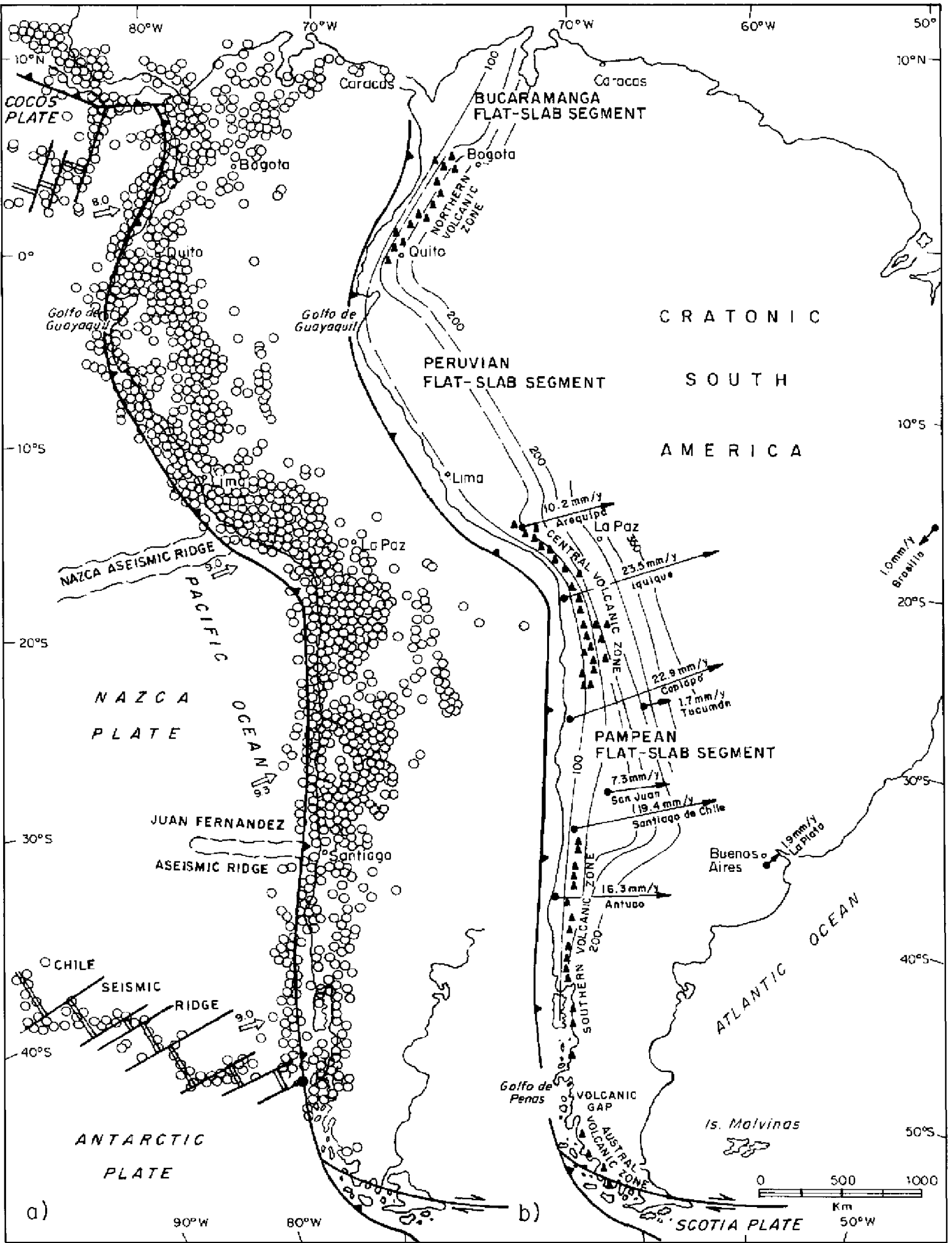

Figure 1 Main geophysical data along the Andes. a) Seismicity (1975-1995) and oceanic features based on U.S.G.S. National Earthquake Information Center; arrows with figures indicate rate and vector of convergence in cm/y. b) Shape of the subducted oceanic plates is shown by contours in kilometers, based on Cahill and Isacks (1992) and Pennington (1981); arrows indicate space geodetic data relative to stable cratonic South America, based on Kendrick et al. (1999). 
along the magmatic arc (Lavenu et al., 1997). As a result of that, shortening and deformation in the foreland areas are minimum, with a significant strike-slip component (Diraison et al., 1998).

The Southern Andes (46 $30^{\prime}-$ $\left.52^{\circ} \mathrm{S}\right)$ are developed south of the triple junction and are the result of uplift associated with ridge collision, along different ridge segments (Ramos and Kay, 1992; Gorring et al., 1997). They concentrate strikeslip deformation in the forearc, but developed an important fold and thrust belt along the Patagonian foreland favored by the virtual absence of magmatic activity of the arc (Ramos, 1989; Alvárez-Marrón et al., 1993).

\section{Seismicity and subduction geometry}

The feature that most strongly characterizes the subduction geometry beneath the Andean Cordillera is the along-strike variation in dip of the subducted Nazca plate from subhorizontal flat-slab segments to normal subduction (Figure 1) (Barazangi and Isacks, 1976; Pennington, 1981; Cahill and Isacks, 1992). The seismic energy released above flat-slab segments is on average 3 or 5 times higher than in the adjacent steeper areas (Gutscher and Malavieille, 1999). Based on the interplate seismicity, several segments of flat-slab subduction have been recognized along the Andes (Figure 1b).

The Northern Andes north of $5^{\circ} \mathrm{N}$ correspond to the Bucaramanga segment, where flat-slab subduction has been recognized along the Colombian margin (Pennington, 1981). In this area important intraplate seismicity is recorded in the upper plate, and crustal thickening is combined with significant strike-slip motion. The large

Bucaramanga earthquakes characterize the notable intraplate activity of this segment (Kellogg and Bonini, 1982) as well as the lack of active volcanism.

The other flat-slab segment corresponds to the Peruvian Andes, and it is preserved between the Gulf of Guayaquil and Arequipa $\left(5^{\circ}-14^{\circ} \mathrm{S}\right)$. Along this segment of the Central Andes the Cordillera Blanca tectonic uplift is located, forming one of the highest regions in the Andes. Important intraplate shallow seismicity is detected in the Eastern Cordillera and the Subandean zone as reported by Suárez et al. (1983) and Dorbath et al. (1991). That accounts for the present $4 \mathrm{~mm} / \mathrm{y}$ shortening in Central Peru. This segment is also characterized by the lack of volcanism and by a subhorizontal oceanic slab, dipping about $5^{\circ}$ to the east and northeast for several hundred kilometers (Barazangi and Isacks, 1976). Near $14^{\circ} \mathrm{S}$ there is an abrupt transition to a more steeply inclined zone (Cahill and Isacks, 1992). foreland Subandean basins.

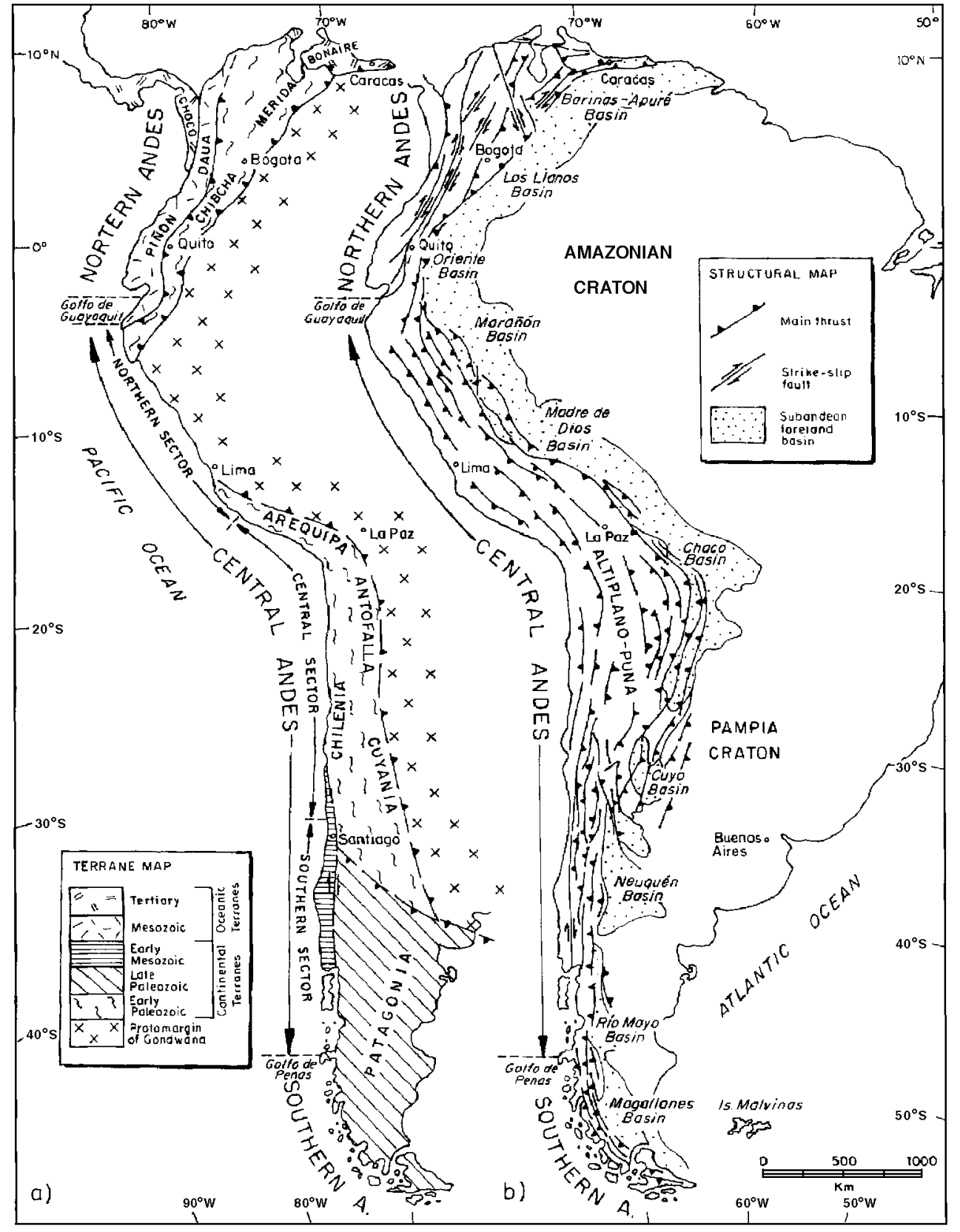

Figure 2 Main geological divisions of the Andes based on Gansser (1973). a) Basement terranes and time of accretion along the Proto-margin of Gondwana. b) Structural framework with main

The third and southern subhorizontal subduction zone corresponds to the Pampean flat-slab segment, and is developed between $27^{\circ} \mathrm{S}$ and $33^{\circ} \mathrm{S}$. The geometry of this segment is well established through a local seismic network (Smalley and Isacks, 1990) that defines a $300 \mathrm{~km}$ horizontal segment, with resumption of eastward descent below $125 \mathrm{~km}$ further east (Cahill and Isacks, 1992). This segment focuses on high intraplate seismicity and is characterized by the lack of volcanism (Figure 1b) and the foreland uplift of the Sierras Pampeanas (Jordan et al., 1983). As a result of that, it is home to the highest mountains along the Main Andes, such as the Aconcagua massif (Ramos et al., 1996).

Between the Bucaramanga and the Peruvian flat-slab segments there is a normal subduction sector where the slab dips $35^{\circ}$ in the Cauca and Ecuador segments (Pennington, 1981). Further south, between Arequipa and Northern Argentina there is the most important normal subduction sector, where the slab inclines $30^{\circ}$ to the east. 
This sector of Southern Peru-Bolivia-Northern Argentina, has an abrupt dip change between $14^{\circ}$ and $16^{\circ} \mathrm{S}$ in the north, and a smooth transition between $24^{\circ}$ and $27.5^{\circ} \mathrm{S}$ in the south. This central sector encompasses the best-developed mountain chains and is the paradigm of Andean-type orogen (Allmendinger et al., 1997). South of $33^{\circ} \mathrm{S}$, the Andes have small variations in the Wadati-Benioff zones, and decreasing seismic activity. The normal subduction extends from $33^{\circ}$ to $46^{\circ} 30^{\prime} \mathrm{S}$ up to the Chile triple junction between the Nazca, South America, and Antarctic plates.

The Wadati-Benioff geometry is dipping $30^{\circ}$ to the east between $33^{\circ} \mathrm{S}$ and $36^{\circ} \mathrm{S}$, and is deepening to about $40^{\circ}$ further south (López et al., 1997).

South of the triple junction, seismicity resumes, as well as the convergent rate, which drops from 9 to $2.2 \mathrm{~cm} / \mathrm{y}$ (Corvalán, 1981). The almost orthogonal subduction gives place to a more oblique subduction around $50^{\circ} \mathrm{S}$ with dominant strike-slip focal mechanisms, to end in a strike-slip transform boundary with the Scotia plate (Dalziel, 1986).

\section{Volcanic arc and related magmatism}

The subduction geometry defines four distinctive zones of active volcanism: the Northern Volcanic Zone $\left(5^{\circ} \mathrm{N}\right.$ to $\left.2^{\circ} \mathrm{S}\right)$ developed along the Cauca and Ecuador segments, the Central Volcanic Zone $\left(16^{\circ} \mathrm{S}\right.$ to $\left.26^{\circ} \mathrm{S}\right)$ between southern Peru and Northern Chile, the Southern Volcanic Zone $\left(34^{\circ} \mathrm{S}\right.$ to $\left.46^{\circ} 30^{\prime} \mathrm{S}\right)$, and the Austral Volcanic zone, south of $47^{\circ} \mathrm{S}$ (Thorpe and Francis, 1979; Thorpe, 1984; Stern and Kilian, 1996). Each volcanic zone has its own peculiarities.

The Northern Volcanic Zone comprises a series of active volcanoes developed in the Western and Central Cordilleras of Colombia south of $5^{\circ} \mathrm{N}$, such as the Nevados de Ruiz, Galeras, and Cerro Bravo (Méndez Fajury, 1989). This zone continues in the interandean depression of Ecuador, where several volcanoes, such as Mojanda, Chimborazo and Pichincha, persist up to $2^{\circ} \mathrm{S}$ (Hall and Beate, 1991; Robin et al., 1997). The volcanic rocks of these volcanoes range from basaltic andesite to andesite, and are more primitive than the products of the central volcanic zone (Thorpe, 1984). They are located in the vicinity of the suture between the Piñon-Dagua oceanic terrane accreted during the Late Cretaceous period and the Paleozoic margin of Gondwana. Their volcanic rocks are consistent with derivation from fractional crystallization of basaltic magmas produced from partial melting of the astenospheric wedge containing components from the oceanic lithosphere. However, their low-tomoderate $\mathrm{Sr}^{87} / \mathrm{Sr}^{86}$ ratios (0.7036 to 0.7046$)$, as well as the higher $\mathrm{Pb}$ - and $\mathrm{O}$-isotope ratios, may indicate some assimilation of younger continental crust (Harmon et al., 1984).

The Central Volcanic Zone is widely developed between Arequipa and Northern Chile, along the Western Cordillera, which bounds the Altiplano-Puna high plateau. Hundreds of volcanoes are widely spread along this region. These volcanoes are characterized by their eruption in a thick crust, in places over $70 \mathrm{~km}$ thick and record high degrees of differentiation. Stravolcanoes constructed largely from andesitic and dacitic lavas are dominant, as well as significant volumes of dacitic ignimbrites of the latest Cenozoic age (Davidson et al., 1993). $\mathrm{Sr}^{87} / \mathrm{Sr}^{86}$ ratios vary from 0.7056 to 0.7149 (Harmon et al., 1984). There is also a striking correlation between the $\mathrm{Pb}$-isotopes of the volcanic rocks and those of the underlying basement (Wörner et al., 1994). These facts, together with the chemical and isotopic composition, led Hildreth and Moorbath (1988) and Davidson et al. (1993), to assume that extensive modification of the mantle-derived magmas took place, as they ascend through an exceptionally thick crust. The amount of contamination has been evaluated in the order of 35 to $70 \%$ (Hawkesworth and Clarke, 1994). On the other hand, subduction of oceanic and terrigenous sediments into the astenospheric wedge, as well as subduction erosion, could have contributed to the differentiation of the mantle-derived magmas (Stern, 1991). Subduction geometry changed during late Cenozoic times, as recorded by the magmatism and by an extensive episode of rhyolitic and dacitic calderas and ignimbritic flows formed during an episode of steepening of the Wadati-Benioff zone (Coira et al., 1994; Kay et al., 1999). The southern part of this Central Volcanic Zone records a crustal delamination associated with mafic magmas and extension (Kay et al., 1994).

The Southern Volcanic Zone is developed between 33 $30^{\prime}$ ' and $46^{\circ} 30^{\prime} \mathrm{S}$, and corresponds to the southern part of the Central Andes. It comprises late Cenozoic and active volcanoes such as Tupungato, San José, Lonquimay, and Hudson, mainly developed on the Chilean slope of the main Andean Cordillera. The northern sector of this $1,000-\mathrm{km}$-long volcanic chain has more crustal influence and is characterized by andesites and dacites (López Escobar et al., 1995). South of $37^{\circ} \mathrm{S}$, the volcanic province consists of basalts to rhyolites, but with a predominance of basalts and basaltic andesites with low $\mathrm{Sr}^{87} / \mathrm{Sr}^{86}$ ratios (0.7037 to 0.7044$)$. This volcanic province is heavily controlled by the onset of important strike-slip faults, such as the Iquiñe-Ofqui (Hervé, 1994). The increasing angle of subduction south of $35^{\circ} \mathrm{S}$ from $30^{\circ}$ to near $40^{\circ}$ beneath the volcanic zone as well as the migration toward the trench recorded since Pliocene times, may account for the minimum coupling between the Nazca and the South America plates, and the dominant poorly differentiated volcanism (Stern, 1990).

The Austral Volcanic Zone has been recently defined by Stern and Kilian (1996). This volcanic zone consists of a few volcanoes developed in the Southern or Patagonian Andes south of the volcanic gap (Figure 1b) associated with the ridge subduction (Stern et al., 1976). Adakitic volcanic rocks of low $\mathrm{Sr}^{86 / 87}$ ratio, formed by components of the astenospheric wedge, plus a partial melting of the subducted slab constitute the poorly evolved lavas of the Lautaro, Aguilera, Diablo, Burney and Cook volcanoes (Stern and Kilian, 1996).

The areas of slab-flat subduction record the shifting, expansion, and cessation of the volcanic arc through time, with striking compositional changes, declining volumes of volcanic rocks and unusual petrological characteristics (Kay et al., 1991; Ramos et al. 1991; Kay and Abbruzzi, 1996).

The normal subduction southern segment of the Central Andes records an important retroarc basaltic magmatism of alkaline composition. It is associated with trench-ward migration of the volcanic front (Muñoz and Stern, 1990); a decreasing age of the oceanic crust being subducted (Ramos and Barbieri, 1989) and the presence of transient hot spots (Kay et al., 1993a). Further south, along the Southern Andes, astenospheric windows formed afterwards by ridge subduction control the near trench magmatism, adakites and retroarc plateau basalts (Ramos and Kay, 1992, Kay et al., 1993b).

\section{Crustal thickening and orogenic shortening}

The convergence vector and subduction rate between South America and the Farallon plate during the Paleogene (Pilger, 1984) favored a more orthogonal convergence in the Peruvian margin and in the Fueguian Andes. The continental margins in these sectors have northwestern trends, and therefore the effects of the high convergence rates by the end of the Eocene were more severe. These two segments record an important compression during the Incaic deformation (Vicente, 1972; Galeazzi, 1996). On the other hand, along the Chilean margin stress partitioning of this oblique convergence reactivated strike-slip displacements (Mpodozis et al., 1994) along the Domeyko fault system and the west fissure (Tomlinson, et al. 1994).

The break-up of the Farallones plate into the Cocos and Nazca plates, which occurred at about $25 \mathrm{Ma}$, seems to mark the beginning of a period of higher and more orthogonal convergence rates in most of the Central and Southern Andes (Pardo Casas and Molnar, 1987). This age coincides with the initiation of widespread Miocene magmatism and is a milestone in the geodynamic evolution of the area. The convergence vector and subduction rate were more important 
along the Chilean margin, during the middle and late Miocene (26-8 $\mathrm{Ma}$ ), the time of the onset of the Quechua deformation (Mpodozis and Ramos, 1989).

The Northern Andes underwent an important stress partitioning during the Paleogene and the Neogene, due to the northeast trend of the continental margin. As a result, the oblique component of plate motion is taken up by dextral slip displacements in a series of crustal discontinuities, such as the Paujili-Cauca and Peltetec-Romeral faults (Dewey and Lamb, 1992; Mégard, 1987).

As a result of the several pulses of compression, generally grouped in the Incaic and Quechua deformations, important crustal thickening took place along the Andes. Maximum crustal thickening is observed along the central sector of the Central Andes, where orogenic shortening was the largest (Isacks, 1988; Allmendinger et al., 1997). New crustal balances made across Northern Chile and Bolivia combined crustal shortening constrained by refraction seismic and partial seismic reflection surveys, and orogenic shortening derived from structural cross-sections (Schmitz, 1994; Kley et al., 1999). These balances indicate up to $320 \mathrm{~km}$ of total shortening during the Cenozoic. This area also has the thickest crust of the Andes, beneath the Western Cordillera at about $20^{\circ} \mathrm{S}$. Broad band seismic analyses indicate a 70-74 km thick crust (Beck et al., 1996).

There is a well-defined gradient to the north and south on this shortening, coherent with forearc rotation constrained by paleomagnetism (Isacks, 1988; Beck, 1998). The crustal thickening and orogenic shortening gradients are well established in the southern segment of the Central Andes $\left(22^{\circ} \mathrm{S}\right.$ to $\left.46^{\circ} 30^{\prime} \mathrm{S}\right)$. There is a continuous decline in the thickening of Andean roots with orogenic shortenings from $160-140 \mathrm{~km}$ at $30^{\circ}-32^{\circ} \mathrm{S}$ (Introcaso et al., 1992; Ramos et al., 1996) up to 44 to $20 \mathrm{~km}$ at $37^{\circ}-39^{\circ} \mathrm{S}$ (Martínez et al., 1997).

\section{Orogenic shortening and tectonic styles}

The estimates of crustal thickening and the consequent orogenic shortening impose important constraints to the tectonic style of the Andean Cordillera. Studies over the last 20 years have shown contrasting attempts to understand the mode of structural deformation along the different foreland thrust belts of the Andes. Models with high-angle basement thrusts (Mégard, 1987; Zeil, 1979) alternate in similar regions with thin-skinned deformation (Vicente, 1972; Ramos, 1988; Allmendinger et al., 1990). Tectonic inversion of previous normal faults in recent years has become one of the significant mechanism of thrusting (Daly, 1988; Grier and Dalmeyer, 1990; Manceda and Figueroa, 1995; Ramos et al., 1996; Cristallini et al., 1997; Colletta et al., 1997; Kley et al., 1999). Those areas where seismic control is suitable either show: (1) unequivocal evidence of thin-skinned thrusting, as with the Subandean fold and thrust belt of Bolivia and Northern Argentina (Baby et al., 1992; Mosquera, 1999); (2) salt detachment of the Santiago fold and thrust belt of Peru (Alemán and Marksteiner, 1997); or (3) tectonic inversion, as in the Eastern Cordillera of Colombia (Cooper et al., 1995). However, in areas where the seismic control is inappropriate, crustal balance can be a further constraint on the amount of shortening. For example, in the Subandean Neuquén basin $\left(37^{\circ}-39^{\circ} \mathrm{S}\right)$, several authors have proposed different tectonic styles from thin- to thick-skinned deformation varying from hundreds to tens of kilometers. As indicated by geophysical studies the crustal shortening does not exceed $44 \mathrm{~km}$ $\left(37^{\circ} \mathrm{S}\right)$ to $20 \mathrm{~km}\left(39^{\circ} \mathrm{S}\right)$. These data confine the structural style to thick-skinned systems such as those proposed by Kozlowski et al. (1993) or Zapata et al. (1999), with less than $40 \mathrm{~km}$ of shortening.

In the Northern Andes, where stress partitioning overimposed important strike slip-displacements, crustal thickening of Cenozoic deformation is more difficult to evaluate. Shortening in the most active Neogene region of Eastern Cordillera of Colombia shows a minimum of $68 \mathrm{~km}$ (Cooper et al., 1995), of the same order as the Mérida Andes with 50 to $60 \mathrm{~km}$ of shortening (Colletta et al., 1997).

In spite of the overwhelming evidence of the importance of tectonic inversion of normal faults in the Andes, there is good evidence in some areas of thin-skinned deformation (Ramos et al., 1996). Stress partitioning under oblique subduction, as proposed by Dewey and Lamb (1992), produced notable strike-slip displacements, such as those detected in the Northern Andes (Campbell, 1968; Dengo and Covey, 1993) or in the Southern Andes (Hervé, 1994; Diraison et al., 1998).

\section{Neotectonics and orogenic shortening}

As an active orogenic belt, the Andes record significant neotectonics along the thrust front. Active faults with notable strike-slip displacements have been also documented in the Boconó fault of the Mérida Andes by Schubert (1982) and Schubert and Vivas (1993). Similar settings have been described in the Eastern Cordillera of Colombia with active faulting in the Garzón Massif and in the Guaicáramo fault (van der Wiel, 1991). Further south, active faulting is recorded in the Ecuadorian Andes in the Interandean Depression, associated with Quaternary volcanism (Hungerbuehler et al., 1996). Along the Peruvian Andes contrasting active tectonics takes place in the flatslab segment with contraction and reverse faults (Schwartz, 1988; Sébrier et al., 1988), in comparison with normal active faults at the northern end of the Altiplano (Sébrier et al., 1985). While continuous foreland blind thrusting is seen in the Chaco plains east of the Subandean belt (Mujica y Zorzín, 1996), at the southern end of the Altiplano-Puna high plateau active faulting is dominated by normal faulting (Allmendinger et al., 1997). This normal faulting was explained by collapse originated in body forces by Froidevaux and Isacks (1988) or by stress partitioning of oblique strike-slip faults by Dewey and Lamb (1992).

Further south, active faulting is striking in the Pampean flatslab segment $\left(27^{\circ}-33^{\circ} \mathrm{S}\right)$, where important shortening has been described in the Precordillera and Sierras Pampeanas (Bastías et al., 1990; Costa, 1992). This activity declines to the south, where in the southern normal subduction sector of the Central Andes $\left(34^{\circ}-38^{\circ} \mathrm{S}\right)$, it is less conspicuous, until it disappears between $39^{\circ} \mathrm{S}$ and $46^{\circ} 30^{\prime} \mathrm{S}$. Active faulting is again important at the latitude of the Chile triple junction, where ridge collision is associated with Quaternary faults (Ramos, 1989). Further south active strike-slip faulting controls the onset of intraplate basaltic flows along the northern Magellan Straits.

New space geodetic data record rates and direction of motion across the Andes, mainly between the continental margin affected by the Nazca plate convergence and stable South America (Norabuena et al., 1998). Recent data presented by Kendrick et al. (1999), and illustrated here in Figure $2 \mathrm{~b}$ show significant shortening rates between the western slope of the Andes and the average position of stations located in cratonic stable areas of Argentina and Brazil. The total relative motion is the result of several components, such as (1) transient elastic deformation on the lock portion of plate interface, that can be released during large thrust earthquakes; and (2) permanent deformation through crustal shortening and mountain uplift. The assessment of this permanent deformation is important to weight the Andean shortening. The amount of shortening between Santiago de Chile $(19.4 \mathrm{~mm} / \mathrm{y})$, San Juan $(7.3 \mathrm{~mm} / \mathrm{y})$ and La Plata $(1.9 \mathrm{~mm} / \mathrm{y})$ permits the evaluation of the active shortening within the Main Andes-Precordillera and Sierras Pampeanas in the Pampean flat-slab of Argentina and Chile. These figures indicate a shortening between both slopes of the Andes of $12 \mathrm{~mm} / \mathrm{y}$, and within the Sierras Pampeanas of $5.4 \mathrm{~mm} / \mathrm{y}$. If these figures are compared with those derived from crustal balance of Andean roots $(7.65 \mathrm{~mm} / \mathrm{y})$ or from structural cross sections $(5.25 \mathrm{~mm} / \mathrm{y})$ in the Main Andes at these latitudes, the GPS results are higher. This fact may indicate either a concentration of elastic deformation along the continental margin, or an increase in recent years of the average Neogene shortening. More suitable figures are obtained when the structural shortening computed for the Sierras Pampeanas, mainly the Pie de Palo area (5 $\mathrm{mm} / \mathrm{y}$ in the last $3 \mathrm{My}$ ), one of the most active areas, is compared with the GPS data $(5.4 \mathrm{~mm} / \mathrm{y})$. The similar values may indicate that elastic deformation accumulated in this region is minimum, and, if it 
existed, was released by the large Pie de Palo earthquake in 1977 (Smalley et al., 1993).

Although these values are still preliminary, they illustrate that space-based geodesy is opening a new era for studies of plate convergence along the Andes.

\section{Major problems and concluding remarks}

This brief overview of the Andean Cordillera shows the great variety of geological problems, and is far from being a comprehensive review of the geological processes that led to the present configuration of the Andes. However, from this short discussion several interesting points arise:

1) The strong correlation between intraplate seismicity in the upper plate and foreland deformation along the flat-slab segments. This correlation matches the present geologic characteristics of the Bucaramanga and Pampean segments. However, foreland deformation in the Peruvian flat-slab segment is far from being as conspicuous as in the other segments. This may not be satisfactorily explained by the recent age of the shallowing of the subducted slab.

2) The main magmatic provinces fit in with the present geometry of Wadati-Benioff zones in the active volcanic arc segments. The volcanic gaps are related either to a shallowing of the subduction zone, or to a segment of recent oceanic ridge collision. Although both segments are related to a ridge collision, the flat slab segments coincide with subduction of aseismic ridges (Pilger, 1984). Volcanic gaps related to normal subduction segments coincide on the other hand with collision of active seismic ridges as indicated by present subduction (Stern et al., 1976; Cande and Leslie, 1986), and Paleogene and Neogene ridge subduction (Ramos and Kay, 1992).

3) Crustal thickening and tectonic shortening are favored by a thermally softened lower crust (Isacks, 1988). Subandean foreland thrust belts that account for large thin-skinned shortening are related to lower crustal shortening in the adjacent Altiplano-Puna high plateau. However, thin-skinned belts such as the Argentine Precordillera seem to be only controlled by the rheology of the old early Paleozoic margin, since deformation took place during cold subduction.

4) Evidence of crustal and lithospheric delamination in some areas where crustal thickness reached a maximum critical value seems to be an important process for explaining the unusual changes in the stress field and the basic magmatism associated with normal faulting. However, more geophysical data are required to describe this crustal setting.

5) A recent proposal of subslab mantle flow as the cause of horizontal compressive normal stress at the leading edge of South America should be independently evaluated (Russo and Silver, 1996). This process could have played an important role, since several changes in the Wadati-Benioff geometry has been observed in Cenozoic times.

6) Information on the rate and direction of motion is being obtained by space geodetic data. However, a longer time span of observation is required, as well as an independent assessment of the amount of transient elastic deformation, in order to evaluate the permanent deformation that controls crustal thickening and mountain uplift.

These processes are prominent in the geological history of the Andean basement. Therefore, specific efforts are necessary to understand the nature of the basement as well as the Paleozoic and Mesozoic history of the Andes. The opening of the South Atlantic and the change in trench roll-back velocity have produced a heterogeneous generalized extension that influenced the Andean structural style and the mode of deformation.

\section{Acknowledgments}

This paper benefits from many years of fruitful discussions and joint efforts with many colleagues, in particular, Constantino Mpodozis, Richard Allmendinger, Antenor Alemán, Suzanne Kay, Estanislao Godoy, and Francisco Hervé. Financial support from CONICET, UBA, and the Antorchas Foundation is also acknowledged.

\section{References}

Alemán, A., and Marksteiner, R. M., 1997, Petroleum systems and structural styles in the Santiago fold and thrust belt: A salt-related orogenic belt: $\mathrm{VI}^{\circ}$ Simposio Bolivariano, Bogotá, 1997, Petroleum Exploration in the Subandean Basins, pt. 2, pp. 171-186.

Allmendinger, R.W., Figueroa, D., Snyder, D., Beer, J., Mpodozis, C. and Isacks, B.L., 1990, Foreland shortening and crustal balancing in the Andes at $30^{\circ} \mathrm{S}$ latitude: Tectonics, v. 9, no. 4, pp. 789-809.

Allmendinger, R.W., Jordan, T.E., Kay, S.M. and Isacks, B.L., 1997, The evolution of the Altiplano-Puna Plateau of the Central Andes: Annual Reviews of Earth and Planetary Sciences, v. 25, pp. 139-174.

Alvarez-Marrón, J., McClay, K.R., Harambour, S., Rojas, L. and Skarmeta, J., 1993, Geometry and evolution of the frontal part of the Magallanes foreland thrust and fold belt (Vicuña area), Tierra del Fuego, southern Chile: American Association of Petroleum Geologists Bulletin, v. 77, no. 11, pp. 1904-1921.

Auboin, J.A., Borrello, A.V., Cecione, G., Charrier, R., Chotin, P., Frutos, J., Thiele, R. and Vicente, J.C., 1973, Esquisse paleogeographique et structurale des Andes Meridionales: Revue de Géographie Physique et de Geologie Dynamique, v. XV, no. 1-2, pp. 11-71.

Baby, P., Heráil, G., Salinas, R. and Sempere, T., 1992, Geometric and cinematic evolution of passive roof duplexes deduced from cross section balancing: example from the foreland thrust system of the southern Bolivian Subandean zone: Tectonics, v. 11, no. 3, pp. 523-536.

Barazangi, M. and Isacks, B., 1976, Spatial distribution of earthquakes and subduction of the Nazca plate beneath South America: Geology, v. 4, pp. 686-692.

Bastías, H. E., Uliarte, E., Paredes, J.D., Sánches, A., Bastías, J.A., Ruzycki, L. and Perucca, P., 1990, Neotectónica de la provincia de San Juan, in Bordonaro, O., ed, Geología y Recursos Naturales de la provincia de San Juan, $\mathrm{XI}^{\circ}$ Congreso Geológico Argentino, San Juan, Relatorio, pp. 228244.

Beck, M.E. Jr., 1998, On the mechanism of crustal block rotations in the Central Andes: Tectonophysics, v. 299, pp. 75-92.

Beck, S.L., Zandt, G., Myers, S.C., Wallace, T.C., Silver, P.G. and Drake, L., 1996, Crustal-thickness variations in the central Andes: Geology, v. 24, no. 5, pp. 407-410.

Bosch, M. and Rodríguez, I., 1992, North Venezuelan collisional crustal block: the boundary between the Caribbean and Southamerican plates: Journal of South American Earth Sciences, v. 6, no. 3, pp. 133-144.

Cahill, T. and Isacks, B.L., 1992, Seismicity and the shape of the subducted Nazca plate: Journal of Geophysical Research, v. 97, pp. 17503-17529.

Campbell, C.J., 1968, The Santa Marta wrench fault of Colombia and its regional setting: 4th Caribbean Geology Conference, Transactions, pp. 247-261.

Cande, S.C. and Leslie, R.B., 1986, Late Cenozoic tectonic of the southern Chile trench: Journal of Geophysical Research, v. 91 B1, pp. 471-496.

Coira, B., Mahlburg Kay, S. and Viramonte, J., 1994, Upper Cenozoic magmatic evolution of the Argentine Puna - A model for changing subduction geometry: International Geology Review, v. 35, pp. 677-720.

Colletta, B., Roure, F., de Toni, B., Loureiro, D., Passalacqua, H. and Gou, Y., 1997, Tectonic inheritance, crustal architecture and contrasting structural styles in the Venezuela Andes: Tectonics, v. 16, no. 5, pp. 777-794.

Cooper, M.A., Addison, F.T., Alvarez, R., Coral, M., Graham, R.H., Hayward, A.B., Howe, S., Martínez, J., Naar, J., Peñas, R., Pulham, A.J. and Taborda, A., 1995, Basin development and tectonic history of the Llanos basin, Eastern Cordillera, and Middle Magdalena valley, Colombia: American Association of Petroleum Geologists Bulletin, v. 79, no. 10, pp. 1421-1443.

Corvalán, J., 1981, Paleotectonic map of the Circumpacific region Southeast Quadrant: Circumpacific Council for Energy and Mineral Resources, A.A.P.G., scale 1:10,000,000.

Costa, C.H., 1992, Neotectónica del sur de la Sierra de San Luis: Universidad Nacional de San Luis, Tesis Doctoral (inédita), 390 pp. 
Cristallini, E., Comínguez, A.H. and Ramos, V.A., 1997, Deep structure of the Metan-Guachipas region: Tectonic inversion in northwestern Argentina: Journal of South American Earth Sciences, v. 10, no. 5-6, pp. 403-421.

Daly, M., 1988, Correlations between Nazca/Farallon plate kinematics and forearc evolution in Ecuador: Tectonics, v. 8, no. 4, pp. 769-790.

Dalziel, I.W.D., 1986, Collision and Cordilleran orogenesis: an Andean perspective, in Coward, M.P. and Riers, A.C., eds, Collision Tectonics, Geological Society Special Publication, v. 19, pp. 389-404.

Davidson, J.P., Harmon, R.S. and Wörner, G., 1993, The source of Central Andean magmas: some considerations, in Harmon, R.S. and Rapela, C.W., eds., Andean Magmatism and its tectonic setting, Geological Society of America Special Paper, v. 265, pp. 233-243.

Dengo, C.A. and Covey, M.C., 1993, Structure of the Eastern Cordillera of Colombia: Implications for traps and regional tectonics: American Association of Petroleum Geologists Bulletin, v. 77, pp. 1315-1337.

Dewey, J.F. and Lamb, S.H., 1992, Active tectonics of the Andes: Tectonophysics, v. 205, pp. 79-95.

Diraison, M., Cobbold, P.R., Rossello, E.A. and Amos, A.J., 1998, Neogene dextral transpression due to oblique convergence across the Andes of northwestern Patagonia, Argentina: Journal of South America Earth Sciences, v. 11, no. 6, pp. 519-532.

Dorbath, L., Dorbath, C., Jiménez, E. and Rivera, L., 1991, Seismicity and tectonic deformation in the Eastern Cordillera and the sub-Andean zone of Central Perú: Journal of South American Earth Sciences, v. 4, no.1-2, pp. 13-24.

Froidevaux, C. and Isacks, B., 1984, The mechanical state of the lithosphere in the Altiplano Puna segment of the Andes: Earth and Science Planetary Letters, v. 71, pp. 305-314.

Galeazzi, J.S., 1996, Cuenca de Malvinas, in Ramos, V.A. and Turic, M.A., eds., Geología y Recursos Naturales de la Plataforma Continental Argentina, XIII ${ }^{\circ}$ Congreso Geológico Argentino y III $^{\circ}$ Congreso de Exploración de Hidrocarburos, Mendoza, 1996, Relatorio 15, pp. 273309

Gansser, A., 1973, Facts and theories on the Andes: Journal of the Geological Society, v. 129, pp. 93-131.

Gorring, M.L., Kay, S.M., Zeitler, P.K., Ramos, V.A., Rubiolo, D., Fernández, M.I. and Panza, J.L., 1997, Neogene Patagonian plateau lavas: continental magmas associated with ridge collision at the Chile Triple Junction: Tectonics, v. 16, no. 1, pp. 1-17.

Grier, M.E. and Dalmeyer, R.D., 1990, Age of the Payogastilla Group: implications for foreland basin development, NW Argentina: Journal of South American Earth Sciences, v. 3, no. 4, pp. 269-278.

Gutscher, M.A. and Malavieille, J., 1999, Style of upper plate deformation linked to interplate coupling over flat slab segments: evidence from the Andean Margin, in McClay, K., ed, Thrust Tectonics 99, London 1999, Abstracts, pp. 214-217.

Hall, M.L., and Beate, B., 1991, El volcanismo plio-cuaternario en los Andes de Ecuador: Boletín del Colegio de Geógrafos del Ecuador, v. 4, pp. 5-17.

Harmon, R.S., Barreiro, B., Moorbath, S., Hoefs, J., Francis, P.W., Thorpe, R.S., Deruelle, B., McHugh, J. and Viglino, J.A., 1984, Regional O-, Sr-, and $\mathrm{Pb}$-isotope relationships in late Cenozoic calc-alkaline lavas of the Andean Cordillera: Journal of the Geological Society, v. 141, no. 5, pp. 803-822.

Hawkesworth, C. and Clarke, C., 1994, Partial melting in the Lower crust: new constraints on crustal contamination processes in the Central Andes, in Reutter, K.J., Scheuber, E. and Wigger, P.J., eds, Tectonics of the Southern Central Andes, Structure and Evolution of an Active Continental Margin: Berlin, Springer Verlag, pp. 93-101.

Hervé, F., 1994, The Southern Andes between $39^{\circ}$ and $44^{\circ} \mathrm{S}$ Latitude: the geological signature of a transpressive tectonic regime related to a magmatic arc, in Reutter, K.J., Scheuber, E. and Wigger, P.J., eds, Tectonics of the Southern Central Andes, Structure and evolution of an active continental margin: Berlin, Springer Verlag, pp. 249-261.

Hildreth, W. and Moorbath, S., 1988, Crustal contributions to arc magmatism in the Andes of Central Chile: Contributions to Mineralogy and Petrology, v. 98 , pp. 455-489.

Hungerbuehler, D., Steinmann, M., Winkler, W. and Seward, D., 1996, Neogene fission-track stratigraphy of the southern Ecuadorian basins: Implications for regional tectonic history: 3rd International Symposium of Andean Geodynamics, Saint-Malo, 1996, ORSTOM, pp. 387-390.

Introcaso, A., Pacino, M. C. and Fraga, H., 1992, Gravity, isostasy and Andean crustal shortening between latitudes $30^{\circ}$ and $35^{\circ} \mathrm{S}$ : Tectonophysics, v. 205, no. $1-3$, pp. 31-48

Jordan, T.E., Isacks, B., Ramos, V.A. and Allmendinger, R.W., 1983, Mountain building in the Central Andes: Episodes, v. 1983, no. 3, pp. 20-26.
Kay, S.M. and Abbruzzi, J.M., 1996, Magmatic evidence for Neogene lithospheric evolution of the Central Andean "flat-slab" between $30^{\circ}$ and $32^{\circ} \mathrm{S}$ : Tectonophysics, v. 259, pp. 15-28.

Kay, S.M., Coira, B. and Viramonte, J., 1994, Young mafic backarc volcanic rocks as indicators of continental lithospheric delamination beneath the Argentina Puna Plateau, Central Andes: Journal of Geophysical Research, v. 99, pp. 24323-24339.

Kay, S.M., Mpodozis, C. and Coira, B., 1999, Neogene magmatism, tectonism, and mineral deposits of the Central Andes $\left(22^{\circ} \mathrm{S}\right.$ to $\left.33^{\circ} \mathrm{S}\right)$, in Skinner, B. et al., eds, Geology and Mineral Deposits of Central Andes, Society of Economic Geology Special Publication, v. 2, pp. 1-35.

Kay, S.M., Ramos, V.A. and Márquez, M., 1993b, Evidence in Cerro Pampa volcanic rocks for slab-melting prior to ridge-trench collision in southern South America: Journal of Geology, v. 101, pp. 703-714.

Kay, S.M., Mpodozis, C., Ramos, V.A. and Munizaga, F., 1991, Magma source variations for mid to late Tertiary volcanic rocks erupted over a shallowing subduction zone and through a thickening crust in the Main Andean Cordillera $\left(28^{\circ}-33^{\circ} \mathrm{S}\right)$, in Harmon, R.S. and Rapela, C., eds, Andean Magmatism and its Tectonic Setting, Geological Society of America Special Paper, v. 265, pp. 113-137.

Kay, S.M., Ardolino, A., Franchi, M. and Ramos, V., 1993a, Origen de la Meseta de Somún Curá: distribución y geoquímica de sus rocas volcánicas máficas. XII ${ }^{\circ}$ Congreso Geológico Argentino y $\mathrm{II}^{\circ}$ Congreso de Exploración de Hidrocarburos, Mendoza, 1993, Actas 4, pp. 236-248.

Kellogg, J.N., and Bonini, W.E., 1982, Subduction of the Caribbean plate and basement uplifts in the overriding South American plate, Tectonics, v.1, pp. 251-276.

Kendrick, E.C., Bevis, M., Smalley Jr. R.F., Cifuentes, O. and Galban, F., 1999, Current rates of convergence across the Central Andes: estimates from continuous GPS observations. Geophysical Research Letters, v. 26, no. 5 , pp. 541-544.

Kley, J., Monaldi, C.R. and Salfity, J.A., 1999, Along-strike segmentation of the Andean foreland: causes and consequences, Tectonophysics, v. 301, pp. 75-94.

Kozlowski, E., Manceda, R. and Ramos, V.A., 1993, Estructura, in Ramos, V.A., ed, Geología y Recursos Naturales de Mendoza, XII ${ }^{\circ}$ Congreso Geológico Argentino y $\mathrm{II}^{\circ}$ Congreso de Exploración de Hidrocarburos, Mendoza, 1996, Relatorio 18, pp. 235-256.

Lavenu, A., Cembrano, J., Arancibia, G., Deruelle, B., López Escobar, L. and Moreno, H., 1997, Neotectónica transpresiva dextral y volcanismo: Falla Iquiñe-Ofqui, Sur de Chile: $8^{\circ}$ Congreso Geológico de Chile, Antofagasta, 1997, Actas 1, pp. 129-133.

López, G., Hatzfeld, D., Madariaga, R., Barrientos, S., Campos, J., LyonCaen, H., Zollo, A., Giannacone, G. and Kausel, E., 1997, Microsismicidad en la zona centro-sur de Chile: $7^{\circ}$ Congreso Geológico de Chile, Antofagasta, 1997, Actas 3, pp. 1771-1774.

López Escobar, L., Cembrano, J., and Moreno, H., 1995, Geochemistry and tectonics of Chilean Southern Andes basaltic Quaternary volcanism ( $37^{\circ}$ $46^{\circ} \mathrm{S}$ ): Revista Geológica de Chile, v. 22, no. 2, pp. 219-234

Manceda, R. and Figueroa, D., 1995, Inversion of the Mesozoic Neuquén rift in the Malargüe fold-thrust belt, Mendoza, Argentina, in Tankard, A.J., Suárez, R. and Welsink, H.J., eds, Petroleum Basins of South America, American Association of Petroleum Geologists Memoir, v. 62, pp. 369 382.

Martínez, M.P., Gímenez, M.E., Introcaso, A. and Robles, J.A., 1997, Excesos de espesores corticales y acortamientos andinos en tres secciones ubicadas en $36^{\circ}, 37^{\circ}$ y $39^{\circ}$ de latitud sur: $8^{\circ}$ Congreso Geológico Chileno, Antofagasta, 1997, Actas 1, pp. 101-105.

Mégard, F., 1987, Cordilleran Andes and Marginal Andes: a review of Andean geology north of the Arica elbow ( $\left.18^{\circ} \mathrm{S}\right)$, in Monger, J.M.H. and Francheteau, J., eds, Circum-Pacific orogenic belts and evolution of the Pacific Ocean basin, International Lithosphere Program Contribution, Geodynamic Series v. 18, pp. 71-96.

Méndez Fajury, R. A., 1989, Catálogo de volcanes activos de Colombia: Boletín Geológico del Ingeominas, v. 30, no. 3, pp. 1-75.

Mosquera, A., 1999, Evolución temporal de la deformación en las Sierras Subandinas Orientales: $\mathrm{IV}^{\circ}$ Congreso de Exploración y Desarrollo de Hidrocarburos, Mar del Plata, 1999, Actas II, pp. 573-568

Mpodozis, C. and Ramos, V.A., 1989, The Andes of Chile and Argentina, in Ericksen, G.E., Cañas Pinochet, M.T. and Reinemud, J.A., eds, Geology of the Andes and its relation to hydrocarbon and mineral resources, Circumpacific Council for Energy and Mineral Resources, Earth Sciences Series, v. 11, pp. 59-90.

Mpodozis, C., Tomlinson, A.J. and Cornejo, P.C., 1994, Acerca del control estructural de intrusivos eocenos y pórfidos cupríferos en la región de Potrerillos-El Salvador: $7^{\circ}$ Congreso Geológico Chileno, Concepción, 1994, Actas II, pp. 1596-1600. 
Mujica, H.J. and Zorzín, V., 1996, Extensión oriental de la tectónica andina en la llanura salteña, Provincia de Salta: XIII ${ }^{\circ}$ Congreso Geológico Argentino y III $^{\circ}$ Congreso Exploración de Hidrocarburos, Buenos Aires, 1996, Actas I, pp. 385-398.

Muñoz, J. and Stern, C., 1988, The Quaternary volcanic belt of the Southern continental margin of South America: transverse structural and petrochemical variations across the segment between $38^{\circ} \mathrm{S}$ and $39^{\circ} \mathrm{S}$ : Journal of South American Earth Sciences, v.1, no. 2, pp. 147-162.

Norabuena, E., Leffler-Griffin, L., Mao, A., Dixon, T., Stein, S., Sacks, I.S., Ocola, L. and Ellis, M., 1998, Space geodetic observations of NazcaSouth America convergence across the Andes: Science, v. 279, pp. 358362.

Pardo Casas, F. and Molnar, P., 1987, Relative motion of the Nazca (Farallon) and South American Plates since Late Cretaceous time: Tectonics, v. 6 , no. 3, pp. 233-248.

Pennington, W.D., 1981, Subduction of the Eastern Panama Basin and seismotectonics of Northwest South America: Journal of Geophysical Research, v. 86, pp. 10753-10770.

Pilger, R.H., 1984, Cenozoic plate kinematics, subduction and magmatism: South American Andes: Journal of the Geological Society, v. 141, pp 793-802.

Ramos, V.A., 1988, The tectonics of the Central Andes: $30^{\circ}$ to $33^{\circ} \mathrm{S}$ latitude, in Clark, S. and Burchfiel, D., eds, Processes in continental lithospheric deformation, Geological Society of America Special Paper, v. 218, pp. $31-54$

Ramos, V.A., 1989, Foothills structure in Northern Magallanes Basin, Argentina: American Association of Petroleum Geologists Bulletin v. 73, no. 7 , pp. 887-903

Ramos, V.A. and Barbieri, M., 1989, El volcanismo Cenozoico de Huantraico: edad y relaciones isotópicas iniciales, provincia del Neuquén: Asociación Geológica Argentina Revista, v. 43, no. 2, pp. 210223.

Ramos, V.A. and Kay, S.M., 1992, The Southern Patagonian plateau basalts: retroarc testimony of a ridge collision, Argentina, in Oliver, R.A., VatinPerignon, N. and Laubacher, G., eds, Andean Geodynamics Symposium, Grenoble, 1992, Tectonophysics v. 205, pp. 261-282.

Ramos, V.A., Munizaga, F. and Kay, S.M., 1991, El magmatismo cenozoico a los $33^{\circ} \mathrm{S}$ de latitud: geocronología y relaciones tectónicas: $\mathrm{VI}^{\circ}$ Congreso Geológico Chileno, Viña del Mar, 1991, Actas I, pp. 892-896.

Ramos, V.A., Aguirre Urreta, M.B., Alvarez, P.P., Cegarra, M., Cristallini, E.O., Kay, S.M., Lo Forte, G.L., Pereyra, F. and Pérez, P., 1996, Geología de la Región del Aconcagua, Provincias de San Juan y Mendoza: Dirección Nacional del Servicio Geológico Anales, v. 24, pp. 1510.

Robin, C., Hall, M., Jímenez, M., Monzier, M. and Escobar, P., 1997, Mojanda volcanic examples (Ecuador): development of two adjacent contemporaneous volcanoes with contrasting eruptive styles and magmatic suites: Journal of South American Earth Sciences, v. 10, no. 5-6, pp. 345-359.

Russo, R.M. and Silver, P.G., 1996, Cordillera formation, mantle dynamics, and the Wilson cycle: Geology, v. 24, no. 6, pp. 511-514.

Schmitz, M., 1994, A balanced model of the southern Central Andes: Tectonics, v. 13, no. 2, pp. 484-492.

Schubert, C., 1982. Neotectonics of Boconó fault, Western Venezuela: Tectonophysics, v. 85 , pp. 205-220

Schubert, C., and Vivas, L., 1993, El Cuaternario de la Cordillera de Mérida, Andes Venezolanos: Universidad de Los Andes, Fundación Polar, Mérida, 345 p.

Schwartz, D., 1988, Paleoseismicity and neotectonics of the Cordillera Blanca fault zone, Northern Peruvian Andes: Journal of Geophysical Research, v. 93, pp. 4712-4730.

Sébrier, M. and Soler, P., 1991, Tectonics and magmatism in the Peruvian Andes from Late Oligocene time to the present, in Harmon, R.S. and Rapela, C.W., eds, Andean magmatism and its tectonic setting, Geological Society of America Special Paper, v. 265, pp. 259-276.

Sébrier, M., Mercier, J.L., Mégard, F., Laubacher, G. and Carey-Gaihardis, E., 1985, Quaternary normal and reverse faulting and the state of stress in the central Andes of south Peru: Tectonics, v. 7, pp. 739-780.

Sébrier, M., Mercier, J.L., Macharé, J., Bonnot, D., Cabrera, J. and Blanc, J.L., 1988, The state of stress in an overriding plate situated above a flat slab: The Andes of central Peru: Tectonics, v. 7, pp. 895-928.

Smalley, R., Pujol, J., Regnier, M., Ming Chiu, J., Chatelain, J.L., Isacks, B., Araujo, M. and Puebla, N., 1993, Basement seismicity beneath the Andean Precordillera thin-skinned thrust belt and implications for crustal and lithospheric behaviour: Tectonics , v. 12 no. 1, pp. 63-76.
Stern, C.R., 1990, Pliocene to present migration of the volcanic front, Andean Southern Volcanic zone: Revista Geológica de Chile, v. 16, no. 2, pp. 145-162.

Stern, C.R., 1991, Role of subduction erosion in the generation of Andean Magmas: Geology, v. 19, no. 1, pp. 78-81.

Stern, C. and Kilian, R., 1996, Role of the subducted slab, mantle wedge and continental crust in the generation of adakites from the Andean Austral Volcanic Zone: Contributions to Mineralogy and Petrology, v. 123, pp. 263-281.

Stern, C., Skewes, M.A., and Durán, M., 1976, Volcanismo orogénico en Chile Austral: I ${ }^{\circ}$ Congreso Geológico Chileno, Santiago, 1976, Actas II(F), pp. 195-212.

Suárez, G., Molnar, P. and Burchfield, B.C., 1983, Seismicity, fault plane solutions, depth of faulting, and active tectonics of the Andes of Peru, Ecuador and southern Colombia: Journal of Geophysical Research, v. 88, pp. 10403-10428.

Thorpe, R.S., 1984, The tectonic setting of active Andean volcanism, in Harmon, R.S. and Barreiro, B.A., eds, Andean Magmatism, Cheshire, Shiva Pub. Ltd., pp. 4-8.

Thorpe, R.S. and Francis, P.W., 1979, Variations in Andean andesite compositions and their petrogenetic significance: Tectonophysics, v. 57, pp. 53-70.

Tomlinson, A.J., Mpodozis, C., Cornejo, P., Fernández, C.F. and Dumitru, T., 1994, El sistema de fallas Sierra Castillo-Agua Amarga: transpresión sinistral eocena en la Precordillera de Potrerillos-El Salvador: $7^{\circ}$ Congreso Geológico Chileno, Concepción, 1994, Actas II, pp. 1459-1463.

Van der Wiel, A.M., 1991, Uplift and volcanism of the SE Colombian Andes in relation to Neogene sedimentation in the Upper Magdalena Valley, Thesis University of Wageningen, Amsterdam, $208 \mathrm{p}$.

Vicente, J.C., 1972, Apercu sur l'organization et l'evolution des Andes argentino-chiliennes centrales au paralléle de Aconcagua: XXIV International Geological Congress, Ottawa, 1972, section 3, pp. 423-436.

Wörner, G., Moorbath, S., Horn, S., Entenmann, J., Harmon, R.S., Davidson, J.P. and López Escobar, L., 1994, Large- and fine.scale geochemical variations along the Andean Arc of Northern Chile $\left(17.5^{\circ}-22^{\circ} \mathrm{S}\right)$. in Reutter, K.J., Scheuber, E. and Wigger, P.J., eds, Tectonics of the Southern Central Andes, Structure and Evolution of an Active Continental Margin Berlín, Springer Verlag, pp. 77-91.

Zapata, T.R., Brissón, I. and Dzelalija, F., 1999, The role of basement in the Andean fold and thrust belt of the Neuquén basin. in McClay, K., ed, Thrust Tectonics 99, London 1999, Abstracts, pp. 122-124.

Zeil, W., 1979, The Andes: A Geological Review: Gebruder Borntaeger, pp. $1-260$.

Victor A. Ramos is professor in tectonics, and head of the Laboratorio de Tectónica Andina at the Universidad de Buenos Aires. His interest on the Andes started soon after his graduation in 1965, after which he devoted most of his professional career in studies about plate tectonics processes and the history of amalgamation of South America. He is chairman of the Andean Subcommittee of the International Commission of the Lithosphere, honorary member of the Geological Society of America, and fellow of the Third World Academy of Sciences.

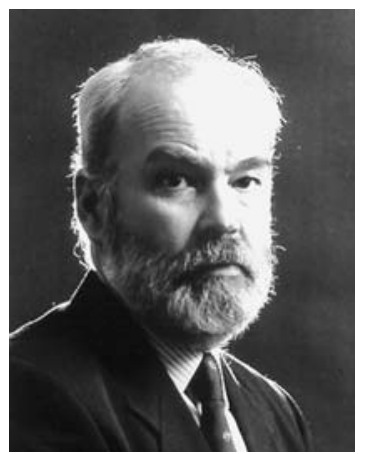

